\title{
EKSISTENSI DAN KEHUJJAHAN URF SEBAGAI SUMBER ISTIMBATH HUKUM
}

\author{
Lailita Fitriani \\ Mahasiswa Institut Agama Islam Negeri Tulungagung \\ Email : lailitafitriani2@gmail.com \\ Luthfa Surya Anditya \\ Mahasiswa Institut Agama Islam Negeri Tulungagung \\ Email : suryaanditya12.sp@gmail.com \\ Minahus Saniyyah \\ Mahasiswa Institut Agama Islam Negeri Tulungagung \\ Email : mnhssnyyh@gmail.com \\ Nicken Nawang Sari \\ Mahasiswa Institut Agama Islam Negeri Tulungagung \\ Email: nniken471@gmail.com \\ Iffatin Nur \\ Dosen Institut Agama Islam Negeri tulungagung \\ Email: iffaeltinury@gmail.com
}

\begin{abstract}
The science of Usul Fiqh developed along with the development of Islam to various areas in the Arabian Peninsula. Research by the Usul Fiqh, it is necessary because many cultures outside of the Arabian Peninsula, which are at odds with the local culture of the Arabian Peninsula. Of course, it is a requirement of local communities who do not know much about Islam. Therefore, the clergy continue to do a lot of efforts to resolve the various problems that exist. Where it is constituted by several methods for the formulation of Islamic law in addition to the "al-Quran", "Sunna", "Ijma'" and "Analogy" which has been agreed upon by both parties, namely al-urf. For Muslims, wherever they are, for the law of the provisions of the Quran and the Hadith of the Prophet is not violated, local customs can be declared valid. Legal ijtihadiyah derived from the "custom" and then set as Islamic law where if the "custom" is a source of that change, then the law ijtihadiyah will also change. The Compilation of Islamic Law contains a consideration of the customs law which is used as the legal basis that there was product fiqh of marital property which is distinct different with the corpus of jurisprudence outside Indonesia. The basic example is based on the reality if the law changes to suit the turn of time, place, and conditions. From here it looks that the nature of Islamic law that dynamic can be seen very clearly.
\end{abstract}

Keywords : 'urf, Islamic law, and ijtihad 


\section{A. Pendahuluan}

Dalam kaidah asasiyah hukum islam terdapat kaidah al-'adat muhakkamat atau adat dapat menjadi pertimbangan hukum. Kaidah ini dapat dimaknai sebagai adat kebiasaan masyarakat yang dijadikan sandaran hukum, selama adat tersebut tidak menyalahi atau bertentangan dengan agama Islam secara teologi, maka dapat dijadikan sebagai tradisi di Islam. Hukum Islam memberi ruang akomodasi kepada adat sehingga hukum Islam memiliki sifat fleksibel dan universal, wajah Islam di dunia tidak harus sama (monolitik). Yang terpenting di dalam keanekaragaman tersebut, haruslah dilingkupi oleh kesatuan manhaj (wihdat al-manhaj) yakni Al-Nabawiy Al-Muhammadiy. Maka, al-Urf ataupun al-Adat perlu dipertimbangkan dalam struktur tubuh hukum Islam.

Secara garis besar, hukum Islam dibagi menjadi dua, yaitu hukum wadh'i dan hukum taklifi. Hukum taklifi menjelaskan tentang perintah dan larangan yang wajib, sunnah, makruh, mubah, dan haram. Sedangkan hukum wadh'i menjelaskan mengenai ketentuan hukum yang mengatur tentang syarat, sebab dan penghalang (mani'), sah, fasad, batal, azimah, dan rukhshah. Hukum-hukum ini dijelaskan dalam al-Quran ataupun al-Hadits, namun ada juga yang tidak dijelaskan dalam kedua sumber hukum Islam tersebut. Sehingga para ulama merasa perlu untuk melakukan metode penentuan hukum Islam yang tidak/belum dijelaskan secara terang di dalam Al-Quran dan Hadits.

Awalnya, ulama berpijak pada al-Quran, Hadits, dan Ijtihad dari para sahabat. Setelah Islam tumbuh dewasa \& banyak negara bergabung dengan daulah Islamiyah, semakin banyak pula budaya yang masuk dan mengakibatkan munculnya berbagai pertanyaan tentang budaya baru \& berbeda yang mana tidak ada pada zaman Rasulullah. Oleh karena itu, pakar Ushul Fiqih menulis kaidah yang sesuai dengan tata bahasa Arab serta sesuai dengan dalil yang digunakan ulama penyusun ilmu fiqih.

Ilmu Ushul Fiqih mulai tumbuh \& berkembang seiring dengan menyebarnya Islam di luar wilayah Jazirah Arab. Perlu adanya penelitian Ushul Fiqih karena banyaknya budaya dari luar yang baru \& berbeda bahkan bertentangan dengan kebudayaan di Jazirah Arab. Tentu hal semacam ini menjadi suatu kebutuhan warga setempat yang belum begitu memahami dan tahu tentang ajaran Islam. Sehingga banyak upaya para ulama untuk memecahkan masalah-masalah tersebut, yang berlandaskan metode penerapan hukum Islam di luar al-Quran, hadits, ijma', dan Qiyas yang telah dimufakati bersama, yakni al-Urf.

\section{B. Pembahasan}

\section{Pengertian}

Kata 'urf secara bahasa berasal dari kata akar di dalam bahasa Arab yang artinya mengetahui, setelah digunakan sering dikenal dalam arti terbiasa, diterima dan dianggap baik oleh akal pikiran. ${ }^{1}$ Abdul Wahhab khalaf berpendapat dan menjelaskan bahwa sesuatu yang dilakukan oleh lebih dari 1 orang atau disebut juga dengan orang banyak baik dari perbuatan, perkataan,

${ }^{1}$ A. Hanafi, Pengantar dan Sejarah Hukum Islam, (Jakarta: Bulan bintang, 1970), h. 77. 
maupun sesuatu yang telah ditinggalkan disebut sebagai 'urf. Hal tersebut dikenal juga sebagai adat. Para ahli hukum islam ikut mengeluarkan pendapat bahwa antara adat dan 'urf tidak memiliki perbedaan. ${ }^{2}$ 'Urf menurut ulama' fikih diusulkan sama dengan adat. Adat merupakan kegiatan masyarakat yang sudah lazim dilakukan dan diwariskan dari generasi ke generasi, walaupun ada yang menyamakannya dengan adat istiadat, namun ada juga yang menganggap 'urf dan adat itu berbeda. Beberapa ulama lain yang membedakan antara 'urf dan adat, Itu adalah :

1. Al-Jurjaniy dalam bukunya memberikan definisi bahwa 'urf adalah perkataan atau perbuatan yang dapat watak manusia terima dan sejalan dengan logika sehingga hati akan merasa tenang dalam melakukannya. ${ }^{3}$

2. Ahmad Fahmi Abu Sunnah mengutip kitab al-Musthafa karya Imam alGhazali mengartikan 'urf atau kebiasaan adalah perkataan atau perbuatan yang dapat diterima oleh pikiran dan karakter orang sehat karena telah menjadi kestabilan hati. ${ }^{4}$

Dari berbagai pendapat tersebut, maka dapat disimpulkan dan diartikan bahwa 'urf dalam istilah adalah segala sesuatu yang diketahui satu sama lain oleh manusia dan mengamalkannya, baik dalam perkataan atau perbuatan atau meninggalkannya. Sedangkan adat diartikan sebagai perbuatan yang diulangulang sehingga menjadi kebiasaan yang harus ditaati oleh masyarakat dalam suatu lingkungan.

Dengan definisi di atas, kita dapat menganggap bahwa 'urf dan adat tidak memiliki perbedaan makna yang jauh. Maka dari itu, seluruh kode etik masyarakat yang berlaku dan memiliki sanksi tetapi belum ada aturannya disebut sebagai hukum adat. Oleh karena itu, hampir seluruh ahli hukum Islam mengatakan pengurangan atau penggantian kata adat dan 'urf tidak memiliki pengaruh dan makna yang berbeda karena istilah adat dan 'urf memiliki arti yang sama dari segi terminologi. Lain halnya dengan ijma', 'urf dan ijma' memiliki perbedaan dan persamaan. Perbedaan tersebut adalah pada 'urf sesuatu dilakukan secara sependapat dan berulang-ulang hingga menjadi kebiasaan oleh masyarakat. Sedangkan ijma' adalah sesuatu yang yang memerlukan ketetapan hukum dari para ahli sebelum dapat dilakukan.

'Urf terbentuk dari rasa saling pengertian masyarakat, meskipun memiliki stratifikasi sosial yang berbeda, yaitu dari semua kalangan masyarakat baik awam maupun alim. Lain halnya dengan ijma' yang dibentuk oleh para mujtahid dan masyarakat awam tidak memiliki andil di dalamnya. ${ }^{5}$

\section{Kedudukan 'Urf sebagai sumber istimbath hukum}

Para ahli hukum islam mengatakan apabila syari' at sejalan sengan 'urf maka itu adalah 'urf yang sah. 'Urf tersebut dapat digunakan sebagai alat bukti dalam mendirikan istimbath hukum, baik itu 'urf amal, 'urf lafadz, 'urf khusus maupun 'urf umum.

Adapun kehujjahan 'urf sebagai sumber istimbath hukum memiliki dasar dari dalil-dalil berikut:

\footnotetext{
${ }^{2}$ Abdul Wahab Khallaf, Ilmu Ushul Fikih, cet. I, (Semarang: Toha Putra Group, 1994), h. 89.

${ }^{3}$ Syarif,, Ali ibn Muhammad al-Jurjaniy, Kitab al-Ta"rifat, (Beirut: Dar al-Kutup al-,,"Ilmiah, 1983), h. 149.

${ }^{4}$ Ahmad Fahmi Abu Sunnah, Al-,,Urf wa al,,Adah fi Ra”y al-Fuqaha”, (Kairon: Lembaga Penerbitan Al-Azhar, 1947), h. 8

${ }^{5}$ Abdul Wahab Khallaf, Ilmu Ushul Fiqih, cet. I, (Semarang: Toha Putra Group, 1994), h.
} 
1. Wahyu kitab suci Al-Qur'an pada surah al-A'raf ayat 199

Artinya, "memaafkan dan menyuruh orang untuk melakukan ma'ruf, dan berbalik kepada orang-orang yang bodoh. Dan jika Anda terkena godaan setan maka berlindung kepada Allah. Sungguh, Allah Maha Tahu".

Melalui makna ayat tersebut, umat islam diperintahkan oleh Allah untuk melakukan ma'ruf. Arti kata ma'ruf adalah kebaikan, dan dilakukan secara berulang-ulang. Menggunakan ajaran agama islam sebagai prinsip pemandunya.

2. Penuturan Abdullah ibnu Mas'ud, teman Rosulullah SAW.

Abdullah ibnu Mas'ud menyampaikan jika adat atau kebiasaan yang dilakukan oleh umat Islam harus sejalan dengan tuntutan hukum Islam secara umum, yaitu sesuatu yang talh ditetapkan oleh Allah. Di sisi lain, halhal yang bertentangan dengan kebiasaan yang dianggap baik di mata masyarakat akan menimbulkan kesulitan dan keterbatasan dalam kehidupan sehari-hari.

Allah berfirman dalam surah al-maidah ayat 6 yang artinya: "Allah tidak akan mempersulit kamu, tetapi Dia ingin menyucikan kamu dan melengkapi nikmatnya untukmu, sehingga kamu bersyukur.

Hukum dan peraturan yang baik adalah yang memperhatikan adat dan kebiasaan masyarakat dalam pembentukannya. Seorang hakim hendaknya memperhatikan perkara seperti ini dalam membuat keputusan. Karena apa yang telah dibiasakan, diketahui, dan disepakati oleh masyarakat pasti sesuai dengan kebutuhan dan memiliki manfaat tersendiri.

Sedangkan adat atau 'urf yang tidak sesuai dengan syari'at wajib ditinggalkan. karena mempertahankan Adat atau 'urf yang buruk dapat dianggap menentang sumber istimbath yang sah. Hukum berdasarkan adat atau 'urf dapat berubah seiring dengan perkembangan zaman karena setiap masalah dapat berubah sewaktu-waktu akibat dari perubahan masalah aslinya. Maka dari itu, para ahli hukum islam mengeluarkan pendapat yang isinya: "Perbedaannya ada pada waktu dan periode, bukan waktu dan alasannya. ${ }^{6}$

\section{Macam-Macam Urf}

Secara umum, ulama membagi urf menjadi tiga sudut pandang, yaitu: ${ }^{7}$

1. Dari segi bentuk/sifatnya, "urf" dibedakan menjadi dua, yaitu:

a. 'Urf Lafdzi merupakan suatu kebiasaan masyarakat saat menggunakan / melafalkan suatu kata, sehingga memiliki makna tersendiri di benak mereka, sedangkan kata-kata dalam aturan bahasa memiliki arti yang berbeda-beda. contoh:

1) Satu jenis. Kata walad (anak) dapat digunakan untuk anak laki-laki atau perempuan, tetapi adat istiadat Arab hanya mengartikannya sebagai anak laki-laki.

2) Kata dabbah berarti reptil, tetapi di Irak, kata dabbah diartikan sebagai keledai

\footnotetext{
${ }^{6}$ Abdul Wahab Khallaf, Ilmu Ushul Fiqh (Kaidah Hukum Islam), (Jakarta: Pustaka Aman), h.118-119.

${ }^{7}$ Sucipto," “URF SEBAGAI METODE DAN SUMBER PENEMUAN HUKUM ISLAM”,ASAS, Vol. 7, No. 1, Januari

2015,hal.30-31
} 
3) Kata thalaq berarti melepaskan, dan oleh karena itu dipahami sebagai indikasi putusnya hubungan pernikahan.

b. 'Urf amali adalah tindakan yang berhubungan dengan kebiasaan sosial.

Misalnya dalam kasus jual beli tanpa ijin, hal ini sudah menjadi kebiasaan di masyarakat

2. Menurut cakupan atau popularitas sosialnya, 'urf dibedakan menjadi 2, yaitu:

a. Tidak umum, yaitu adat istiadat yang berlaku umum bagi masyarakat dan seluruh wilayah.

Misalnya: mengangkat tanda kecil berwarna hijau, kuning atau hitam untuk mengungkapkan kesedihan atas kematian seseorang.

b. Urf Istimewa adalah adat istiadat yang hanya ditetapkan dalam masyarakat tertentu di wilayah atau kelompok tertentu dalam kurun waktu tertentu.

Contoh: Pengembalian (retur) tidak sesuai dengan pesanan semula dan dapat diganti oleh penjual dalam bentuk barang atau uang.

3. Dari perspektif Suriah, dalam hal ruang lingkup atau efektivitas

a. 'Urf shahih, yaitu adat istiadat tidak menentang syari'at dalam masyarakat, tidak akan mengurangi manfaatnya, juga tidak merugikan mereka.

Contoh: Ketika seorang pria ingin menikah dengan seorang wanita, dia memberikannya kepada calon wanita tersebut dalam bentuk hadiah pertunangan / perkawinan, misalnya.

b. 'Urf fasid, yaitu segala hal yang bersifat kebiasaan yang ada dalam masyarakat tetapi bertentangan dengan syariat Islam, karena beberapa dalil mengandung unsur maksiat kepada Allah, dan tidak diperbolehkan tunduk kepada makhluk.

Misalnya: meletakkan kurban di bawah pohon besar atau pohon yang dianggap sakral, tujuannya untuk mencari pertolongan selain Allah, meminum minuman beralkohol di acara tersebut, dan praktek lintah darat. $^{8}$

\section{Sejarah Penggunaan Urf Sebagai Sumber Hukum}

Menurut sejarah, 'urf masyarakat Mekkah maupun Madinah banyak yang diadopsi oleh Rasulullah ketika beliau menetapkan suatu perkara. Meski begitu, tidak semua 'urf tersebut dijadikan sebagai hukum islam, beberapa dimodifikasi dan direvisi agar sesuai dengan ajaran agama islam. beberapa

${ }^{8}$ Fitra Rizal,” PENERAPAN 'URF SEBAGAI METODE DAN SUMBER HUKUM EKONOMI ISLAM”, Al-Manhaj: Jurnal Hukum dan Pranata Sosial Islam, Vol. : 1 (2), 2019,hal.162 
contoh dari adopsi tersebut adalah adanya konsep sunnah taqririyah ${ }^{9}$. Contoh lainnya termasuk dalam perihal ibadah, kita melaksanakan ibadah umrah dan haji sebagaimana yang dipraktekkan oleh masyarakat Arab pada masa pra islam. Seperti: wukuf, ihram, talbiyah dan sebagainya. Perbedaannya adalah Islam melarang bertawaf secara telanjang dan membersihkan ibadah ini dari nuansa syirik. ${ }^{10}$

Setelah Rasulullah wafat, para sahabat tidak menolak mengadopsi sistem dan tradisi masyarakat setempat selama dalil Al-Qur'an dan Hadits tidak menentangnya. Seperti sistem pelayanan pos ketika masa pemerintahan khalifah Umar bin Khattab yang diadopsi dari masa kekaisaran Byzantium.

Sejarah mencatat agama islam telah masuk ke Nusantara pada abad ke-7, ada juga yang mencatat pada abad ke-12 masehi, dibawa oleh para pedagang muslim melalui cara damai dan merangkul penduduk. Agama islam dapat menerima unsur budaya lokal dan mudah beradaptasi sehingga banyak masyarakat yang dengan sukarela masuk islam.

Terdapat hadits yang berbunyi "Sesungguhnya Allah melihat hati hambahamba-Nya setelah Nabi Muhammad SAW, maka Allah menjumpai hati para sahabat merupakan hati yang terbaik. Maka apa yang dipandang oleh mereka sebagai kebaikan maka di sisi Allah sebagai sebuah kebaikan. Dan apa yang dipandang mereka sebagai kejelekan maka di sisi Allah sebagai sebuah kejelekan." (H.R. Ahmad dari Abdullah ibnu Mas'ud). Para ahli ushul fiqih menjadikan hadits tersebut sebagai pemahaman bahwa "urf atau tradisi kebiasaan masyarakat dapat menjadi sumber istinbath hukum asalkan tidak berlawanan dengan dalil maupun prinsip syari'at dalam agama islam.

Beberapa 'urf yang diadaptasi masih dipengaruhi dan berbau ajaran agama lainnnya, seperti agama Hindu. Contohnya kebiasaan meratapi dan bersedih atas mayat orang yang telah meninggal dunia. Setelah islam masuk ke Nusantara, kebiasaan tersebut diislamkan dengan cara memuji Allah, membaca surat Yasin, sholawatan, dan membaca tahlil.

Kaidah di atas memperlihatkan bahwa pada saat itu, kondisi dan situasi kebiasaan masyarakat dunia Arab berbeda sekali dengan kondisi dan juga situasi masyarakat yang ada di Nusantara. Maka dari itu, muncul ide dari para walisongo sebagai penyebar islam di Nusantara untuk mengembangkan ajaran agama islam dengan memanfaatkan tradisi-tradisi dan kebiasaan serta budaya masyarakat lokal. Seperti berdakwah menggunakan seni pewayangan, gamelan, suluk, dan merevisi tradisi suroan.

Hasbi Ash-Shiddiqy berpendapat bahwa dengan cara menggali dan memanfaatkan kebiasaan masyarakat untuk melakukan ijtihad fiqih berciri khas Indonesia, dapat membuat agama islam berkembang dengan lebih baik. ${ }^{11}$

KH. Abdurrahman Wahid juga berpendapat bahwa konsep pribumisasi islam adalah hal yang sangat penting keberadaannya. Konsep tersebut memiliki makna usaha menguatkan Kembali akar tradisi dan kebudayaan dengan selalu berupaya mengadakan lingkungan masyarakat yang taat dalam beragama. Beliau menolak Gerakan "Islamisasi, Arabisasi, Formalisasi ajaran islam

\footnotetext{
${ }^{9}$ Zionis, 137.

${ }^{10}$ Khalil Abdul Karim, Syari'ah Sejarah Perkelahian Pemaknaan, Terjemah Kamran As'ad, LKIS, Yogyakarta 2003, hal

${ }^{11}$ Hasbi Ash-Shiddiqy, Syari'at Islam Menjawab Tantangan Zaman, Bulan Bintang, Jakarta, 1996, hal 43.
} 
dalam ranah budaya". ${ }^{12}$ Seperti penggantian beberapa kosa kata Bahasa Indonesia menjadi Bahasa Arab, contohnya kata "Minggu" diganti menjadi "Ahad".

Terdapat 3 teori sederhana yang lazim digunakan untuk menyambungkan hukum islam dan hukum adat secara historis ${ }^{13}$, yakni:

1. Teori Receptio in Complexu dari Coderwisk William Christian Van Den Berg (1845-1925). Pendapat teori ini adalah peraturan atau hukum setiap agama berlaku untuk masing-masing penduduk. Bagi umat kristiani berlaku hukum kristen, bagi umat muslim berlaku hukum islam, begitu juga untuk umat pemeluk agama lainnnya. Menurut Van dem Berg, hukum islam telah diterima secara menyeluruh oleh orang islam Indonesia. Disebutkan dalam statute Batavia 1642 bahwa hukum islam harus dipergunakan ketika menyelesaikan sengketa antara penduduk muslim, yaitu menggunakan hukum agama yang mereka anut. Hal lain yang mendukung teori ini yakni daerah jajahan VOC dan kerajaan islam nusantara memberlakukan hukum sesuai isi buku hukum munakaha dan mawaris (perkawinan dan warisan) yang disusun, direvisi, dan disempurnakan oleh para ulama'.

2. Teori Receptie oleh Cornelis Van Vallen Hoven dan Christian Snouck Hungrounje (1857-1936). Teori ini mengatakan bahwa hukum yang beraku pada suatu daerah bukanlah hukum agama, melainkan hukum adat. Hukum agama berlaku apabila hukum tersebut telah diterima dan digunakan dalam waktu yang lama kemudian menjadi hukum adat. Contoh dari teori ini yaitu hukum pidana islam tidak berlaku apabila tidak diundangkan di negara Repubik Indonesia meskipun hukum tersebut sumbernya dari dalil Alqur'an, Hadits dan Sunnah. Kemudian, setelah hukum tersebut diundangkan, orang islam masih memiliki pilihan ingin menggunakan hukum islam atau hukum lain, seperti undang-undang tentang peradilan agama no. 7 tahun 1989 .

3. Teori Receptio a Centrario oleh Prof. Hazairin (1909-1975). Menurut Hazairin, hukum adat hanya berlaku apabila tidak berlawanan dengan hukum agama yang dianut masyarakat sekitar. Hal tersebut memiliki makna bahwa kedudukan hukum adat ada di bawah hukum agama. Hukum islam berlaku bagi umat muslim. sehingga negara wajib mengaturnya dalam peraturan yang jelas seperti undang-undang, dan dapat segera dipraktekkan tanpa melewati hukum adat.

\section{Eksistensi 'Urf di Masyarakat Indonesia}

Dalam The Modern Trend in Islam, Sir Hamilton Alexander Rossken mengungkapkan tentang keadaan kebiasaan dan ajaran hukum yang hadir dalam kehidupan bermasyarakat, diadopsi menjadi sifat hukum yang luwes terpadu. Dalam masyarakat islam, peraturan hukum yang digunakan dan berlaku memiliki sumber yang jelas, yaitu pada kaidah fiqhiya $A l$ 'Adah Muhakkamah. Gambaran yang ditunjukkan dari dal tersebut adalah

\footnotetext{
${ }^{12}$ Abdurrahman Wahid, Pribumisasi Islam dalam Muntaha Azhari dan Abdul Mun'im Saleh, Islam Menatap Masa Depan, P3M, Jakarta 2006, hal 96.

${ }^{13}$ Zainuddin Ali, Hukum Islam, Pengantar Ilmu Hukum Islam di Indonesia, Sinar Grafika, Jakarta 2008, hal 8
} 
pembentukan, pelaksanaan, dan ketaatan masyarakat terhadap hukum islam yang sangat kuat dipengaruhi oleh daya asimilasi hukum yang kuat pula. ${ }^{14}$

Di dalam sebuah wilayah, negara, daerah, dan masyarakat sering kita temukan 'urf yang tetap berkembang dan lestari. Namun, tidak sedikit juga yang telah dibuang, dihapus, dan diganti karena syari'at agama, perkembangan norma dan zaman tidak lagi sesuai dengan 'urf atau kebiasaan tersebut. Banyak 'urf yang hadir dalam kehidupan mulai dari lahir hingga meninggal.

Beberapa contohnya yaitu:

1. Adat mitoni sebagai acara syukuran untuk bayi dalam kandungan yang berumur 7 bulan.

2. Adat puputan sebagai acara syukuran setelah tali pusar bayi dipotong.

3. Adat selapanan sebagai acara syukuran atas 35 hari kelahiran bayi.

4. Hingga kebiasaan tahlil sebagai acara kirim doa untuk orang yang telah meninggal sekaligus memperingati 7, 40, 100, 1000 harinya.

Begitu juga dengan adat di Minangkabau yang berpedoman dan berlandaskan pada syara'(Al-Qur'an, Hadits, Sunnah). Sehingga tidak dibenarkan adanya kebiasaan atau adat yang bertentangan dengan syari'at islam.

Terdapat pepatah di Aceh yang berbunyi "Hukum bak syah kual, Adat bak teumeruhun", maksudnya yaitu syari'at atau hukum berpangkal dari ulama, sedangkan adat berpangkal dari raja atau sultan. Syah Kual adalah nama ulama penegak hukum berdasarkan syari'at islam di Aceh. Sehingga adat atau kebiasaan masyarakat Aceh tidak berlawanan dengan hukum atau syari'at agama islam. Dan masih banyak pula 'urf lainnya di masyarakat Indonesia yang sesuai dengan ajaran agama islam.

\section{Persyaratan Penggunaan 'Urf sebagai Dasar Hukum}

'Urf bisa dijadikan argumen menurut hukum Islam, tapi tidak semua urf bisa dijadikan dasar hukum. Hal ini telah disetujui oleh para ulama berikut ini beberapa ulama yang meyakini bahwa 'urf dapat dijadikan dasar hukum Islam adalah:

1. ${ }^{15}$ Imam Malik bersabda, "urf bisa dijadikan dasar hukum, terutama adat istiadat atau kebiasaan masyarakat Madinah ('amalu ahlil madinah'). Penduduk Madinah tinggal bersama Nabi Muhammad SAW Selama kurang lebih 10 tahun itu Dipastikan bahwa masyarakat Madinah sangat menyadari Nabi Muhammad SAW yang dilakukan Nabi SAW setiap hari, sehingga kebiasaan masyarakat Madinah dapat dijadikan dasar hukum yang dibuat oleh Nabi Muhammad SAW.

\footnotetext{
${ }^{14}$ H.A.R. Gibb, The Modern Trends in Islam, Chicago Illionois, The University of Chicago Press, USA 1950, hal 87.

${ }^{15}$ Ahmad Sulthon,"Ushul Fiqih-14” (Blitar:2019),hal.35
} 
2. Imam Syafi'i mengatakan bahwa 'urf dapat digunakan sebagai sumber hukum Islam, sepanjang tidak bertentangan dengan hukum Kuli (syara' / utuh) dan juz'i (sebagian). Sebagai penjual, ada pembeli dan transaksi komoditas, tetapi tidak ada perjanjian jual beli, alasannya adalah mempermudah masyarakat dan menjadi kebiasaan yang diwariskan dari generasi ke generasi.

Adapun ulama yang menolak urf sebagai sumber hukum dalam Islam yaitu:

1. Ulama' Hambali, Ulama' Hambali menolak' urf sebagai sumber hukum dalam Islam, karena 'urf tidak memiliki dasar dalam Alquran dan Sunnah. Nafsu lebih dikendalikan oleh iblis.

Persyaratan "urf" yang dapat dijadikan sumber hukum Islam: ${ }^{16}$

1. 'Urf tidak menyimpang dari hukum Islam

2. Tidak akan menyebabkan kerugian, atau kehilangan manfaatnya,

3. Ini umumnya dilakukan di kalangan Muslim

4. Tidak berlaku untuk sujud

5. 'Urf sudah tidak asing lagi di masyarakat sebelum dijadikan yayasan.

Sementara itu, menurut Al-Zarqa, 'urf dapat digunakan sebagai dasar untuk memberikan hukum Islam jika memenuhi syarat-syarat sebagai berikut:

1. 'Urf dapat diterapkan secara universal dalam artian kebiasaan, kebiasaan ini berlaku untuk apa yang terjadi di masyarakat, dan kebanyakan orang mengadopsi penerapannya.

2. 'Urf sudah ada sejak lama dalam masyarakat tertentu sebelum undangundang diundangkan. Artinya" urf yang harus dijadikan landasan hukum terlebih dahulu adalah sebelum menetapkan undang-undang.

3. 'Urf sebagai dasar tidak berbeda dengan apa yang dinyatakan dengan jelas oleh para pihak dalam masalah langsung.

4. 'Jika tidak ada kata atau kalimat dalam Al-Qur'an atau Sunnah yang dijadikan alasan hukum yang memuat masalah yang harus diselesaikan, maka 'Urf dapat dianggap sebagai dasar hukum Islam. Artinya kalau soal sudah ada teksnya, adat istiadat tidak bisa dijadikan bukti syariat Islam.

${ }^{17}$ Dikutip oleh Satria Effendi dari Abdul Karim Zaidan 'Urf bisa dijadikan dasar

hukum yaitu:

1. 'Urf harus disertakan

'Urf efektif dalam arti tidak bertentangan dengan Alquran dan ajaran.Misalnya, adat istiadat.

Negara tempat aset tepercaya dikembalikan ke istri atau anak penyedia atau pemilik perwalian.

2. Urf harus bersifat umum, dalam arti terkecil sudah menjadi kebiasaan mayoritas penduduk negara.

\footnotetext{
${ }^{16}$ Fitra Rizal, Al-Manhaj: Jurnal Hukum dan Pranata Sosial Islam...hal.163-164

${ }^{17}$ Satria Effendi, Ushul Fiqh, (Jakarta: Kencana Prenada Media Group, 2005),hal.156.
} 
3. 'Urf harus sudah ada pada saat acara berdasarkan 'urf. Misalnya, ada yang menyumbangkan hasil kebunnya kepada ulama, dan yang disebut ulama pada saat itu hanya mereka yang berilmu tapi tidak berilmu,diperlukan ijazah.

4. Konfirmasi pihak terkait berbeda dengan keinginan "urf".

\section{Kesimpulan}

'Urf atau adat merupakan suatu perbuatan yang diketahui dan dilakukan secara berulang-ulang oleh manusia dan menjadi suatu kebiasaan yang harus ditaati, baik secara lisan / perbuatan / meninggalkannya. Kemudian untuk kehujjahannya sendiri, 'urf didasari oleh Firman Allah dalam Q.S al-A'raf ayat 199 dan ucapan Abdullah bin Mas’ud.

Secara umum, 'urf dibagi menjadi 3 sudut pandang, yang pertama berdasarkan sifat /bentuknya ('urf lafdzi dan 'urf amali), yang kedua berdasarkan cakupan sosialnya (tidak umum dan 'urf istimewa), dan yang ketiga berdasarkan efektivitas ('urf shahih dan 'urf fasid). Meninggalkan pembagian 'urf, 'urf berawal dari masyarakat Mekkah ataupun madinah yang kemudian diadopsi oleh Rasulullah untuk menetapkan suatu perkara. 'urf juga diadopsi oleh para sahabat selama Al-Quran dan Hadits tidak menentangnya, bahkan 'urf juga dimanfaatkan oleh para penyebar agama Islam di Nusantara untuk mengembangkan ajaran Islam dengan memanfaatkan tradisi, kebiasaan, dan budaya masyarakat lokal. Di Indonesia sendiri banyak ditemukan 'urf yang tetap berkembang dan lestari, namun tidak sedikit pula yang telah dibuang, dihapus, dan diganti karena syariat agama. Untuk dapat dijadikan sumber hukum, 'urf harus bersifat universal, tidak menyimpang hukum Islam, tidak menyebabkan kerugian, dilakukan di kalangan Muslim, dan tidak berlaku untuk sujud.

\section{Daftar Pustaka}

Abu Sunnah, A. F., 1947. Al-'Urf wa al-'Adah fi Ra'y al Fuqoha'. Kairo: Lembaga penerbit Al-azhar.

Ali, Z., 2008. Hukum Islam:Pengantar Ilmu Hukum Islam di Indonesia. Jakarta: Sinar Grafika.

Al-Jurjaniy, S. '. b., 1983. Kitab al-Ta'rifat. Beirut: Dar al-Kutub al-'Ilmiyah.

Ash-Shiddiqy, H., 1996. Syari'at Islam Menjawab Tantangan Zaman. Jakarta: Bulan Bintang.

Effendi, S., 2005. Ushul Fiqih. Jakarta: Kencana Prenada Media Group.

Gibb, H., 1950. The Modern Trends of Islam. USA: The University of Chicago Press. 
Hanafi, 1970. Pengantar dan Sejarah Hukum Islam. Jakarta: Bulan Bintang.

Karim, A. \& K., 2003. Syari'ah Sejarah Perkelahian Pemaknaan,Terjemah Kamran As'ad.. LKIS penyunt. Yogyakarta: s.n.

Rizal, F., 2019. Penerapan 'Urf Sebagai Metode dan Sumber Hukum Ekonomi Islam. Al-Manhaj: Jurnal Hukum dan Pranata Sosial Islam, 1(2).

Rizal, F., n.d. Al-Manhaj:Jurnal Hukum dan Pranata Sosial Islam.

Sucipto, 2015. 'Urf Sebagai Metode dan Sumber Penemuan Hukum Islam. ASAS, 7(1).

Sulthon, A., 2019. Ushul Fiqih-14. Blitar: s.n.

W, K. A., t.thn. Ilmu Ushul Fiqih (Kaidah Hukum Islam). n.d penyunt. Jakarta: Pustaka Amani.

Wahid, A., 2006. Pribumisasi Islam dalam Muntaha Azhari dan Abdul Mun'in Saleh,Islam Menatap Masa Depan. Jakarta: P3M.

Z. \& Mumazziq, R., 2011. Posisi al-'Urf dalam Struktur Bangunan Hukum Islam. Jurnal Falasifa, 2(2). 